\title{
Determination of Patient Learning Needs after Thyroidectomy
}

\author{
Zeynep Temiz¹, Didem Ozturk²*, Gulay Altun Ugras³, Seher Deniz Oztekin², \\ Emel Sengul ${ }^{4}$
}

\begin{abstract}
The purpose of this study was to determine discharge learning needs of patients undergoing thyroidectomy. The population of this descriptive study consisted of patients undergoing thyroidectomy in the Endocrine Surgery Unit of a university hospital between February and December 2013. The study included 251 patients who were discharged after thyroidectomy. Data obtained using the data collection form and the Patient Leaning Needs Scale (PLNS) were analyzed by frequency, mean, standard deviation, Kruskal Wallis and student-t tests. The mean age of the patients was $47.91 \pm 13.05$ and $76.1 \%$ were females. The PLNS total mean score was $208.38 \pm 34.91$, with the maximum score of $39.23 \pm 6.80$ on the subscale of treatment and complications and the minimum score of $19.45 \pm 4.70$ on the subscale of feelings related to condition. It was found that the PLNS total score of the patients was not influenced by age, gender, marital status $(p>0.05)$. This study demonstrated that patients had high learning needs after thyroidectomy.
\end{abstract}

Keywords: Thyroidectomy - patient learning needs - nursing - post-discharge education

Asian Pac J Cancer Prev, 17 (3), 1479-1483

\section{Introduction}

Recent advances in technology and medicine have shortened the length of hospitalization in patients undergoing surgical procedure and increased tendency to out-patient surgery. Considering patient safety and comfort, resource protection and cost-effectiveness, thyroid surgery is performed as an out-patient procedure in most centers (Terris et al., 2013; Perera, Patel and Law, 2014; Rutledge et al., 2014). In the absence of postthyroidectomy complications, patients are discharged from hospital on the same day of surgery or hospitalized only for one day (Vrabec et al., 2003; Snyder et al., 2010). Therefore, nurses give priority to technical care and patient discharge education is poorly or inadequately provided (Tasocak, 2003; Johansson et al., 2007; Falvo, 2011).

In the lack of optimally efficacious discharge education, or of provision of appropriate information, patients experience more anxiety and problems resulting in unplanned medical visits (Moderchai, Herman, Kerzman and Irony, 2010; Dag et al., 2014). In addition, it has been reported that when patients are concerned and inadequately informed, they feel more dependent. Therefore, nurses should identify the learning needs and knowledge deficits of patients (Johansson et al., 2007; Myers and Pellino, 2009; Falvo, 2011). Throughout the discharge process, nurses are required to assess patient's condition, and provide efficient patient-centered information meeting post-operative individual needs of patients (Sendir, Buyukyılmaz and Musovi, 2003; Johansson et al., 2007; Falvo, 2011; Galdeano et al., 2014; Krishnatreya et al., 2014). It has been reported in the literature that patients obtaining information specific to their health condition experience an accelerated healing process, show better compliance to treatment, have increased self-confidence, satisfaction, coping skills, and quality of life and decreased anxiety and unplanned medical visits, which in turn reduces health care costs and increases the quality of health care (Clark et al., 2005; Mcmurray et al., 2007; Piredda et al., 2008; Williams, 2008; Myers and Pellino, 2009; Fedai, Cetin and Teke, 2010).

Shortened hospital stay enhances the importance of effective use of hospitalization time in terms of discharge education (Tasocak, 2003; Johansson et al., 2007; Falvo, 2011; Sendir, Buyukyılmaz and Musovi, 2013). One of the causes of ineffective use of time has been reported in the literature to be the difference between the patients' perceptions of that which is important information and that of the nurses providing the education. In this context, the time allocated for patient education is wasted with the issues that are perceived as important by nurses and those that patients deem to be important are ignored (Bailey, 2004; K1zıl, 2008). For the appropriate identification of patients' educational needs and priorities at discharge, learning needs should be assessed using appropriate tools. The provision of discharge information specific to patients' 
Zeynep Temiz et al

learning needs can help reduce the number of patients presenting to hospital with concern and anxiety about home care and complications. In the light of these data, this study aimed to identify discharge information needs of patients undergoing thyroidectomy and to contribute to preparation of nurses' discharge education planning on patients' needs.

\section{Materials and Methods}

\section{Setting and Sample}

This descriptive study aimed at identifying discharge learning needs of patients undergoing thyroidectomy at the Endocrine Surgery Unit of Istanbul University, Cerrahpasa Faculty of Medicine. The population of this study consisted of 251 patients undergoing thyroidectomy at the Endocrine Surgery Unit between February and December 2013, who met the study criteria.

The sample size was ensured to be as five-fold of the number of scale items (50 items) in validity and reliability studies. The inclusion criteria were the patients who had been scheduled to be discharged after thyroidectomy, who were oriented to person, place and time and had the ability to speak Turkish, and consented to participate in the study.

\section{Instrument}

The instrument developed by the researchers consisted of two sections. Section one included questions related to patients' characteristics. In section two, "The Patient Learning Needs Scale-PLNS" was used to identify patients' discharge learning needs. This scale was developed by Bubela, Galloway, McCay, McKibbon, Nagle, Pringle, Ross \& Shamian in 1990, with a Cronbach's alpha coefficient of 0.95 (Bubela et al., 1990). In this study, Cronbach's alpha coefficient for the PLNS was 0.95 and that for the subscales ranged between 0.74 and 0.89 . The validity and reliability study was carried out by Catal and Dicle in Turkey in 2008 (Catal and Dicle, 2008).

The PLNS is a 50-item Likert-type scale with 7 subscales. The scale items are scored on a Likert-type scale with, 1: not important 2: less important 3: fairly important 4: very important and 5: extremely important. Accordingly, patients are asked to choose the response that best describes their learning needs and priorities. Result analysis includes assessment of each subscale and total scale scores. The scores obtained from the scale range between 50 and 250 (Bubela et al., 1990).

\section{Procedures}

Data were collected by face-to-face interview technique between February 2013 and December 2013. The scale was administered to patients undergoing thyroidectomy 24-48 hours before discharge. All questions that patients had difficulty in understanding/ interpreting were explained by the researcher who accompanied the patient throughout data collection process. Patients who had difficulty reading questions or marking the responses were assisted by the researcher; the questions were read to the patients and they were given time to understand and choose the response and their responses were marked by the researcher.

\section{Data analysis}

Data were analyzed using "SPSS for Windows 21.0 (IBM Corp., Armonk, New York)". The data were analyzed statistically using frequency, percentage, mean, standard deviation. The Kruskal-Wallis and Student t test were used for the comparison of the groups. A $p$ value of $<0.05$ was considered statistically significant, with a confidence interval of $95 \%$.

\section{Ethical Review}

Prior to the study, a written consent was obtained from the Endocrine Surgery unit of Istanbul University, Cerrahpasa Faculty of Medicine and the study was approved by the Clinical Research Ethics Committee of Istanbul University Cerrahpasa Faculty of Medicine.

Before the administration of data collection tools, patients were informed about the purpose and content of the study. The patients were ensured that their privacy would be kept, their responses were to remain completely confidential and to be only used for scientific purposes by the researcher. A written and verbal consent was obtained from each patient.

\section{Results}

The mean age of the patients enrolled in this study (n:251) was $47.91 \pm 13.05$. Of all patients, $76 \%$ were females, $82.5 \%$ were married, $34.7 \%$ had primary education level, and $15.9 \%$ had concerns about home care.

Table 1 presents the PLNS mean scores of the patients. The PLNS total mean score of the patients was $208.38 \pm 34.91$. The highest mean score was obtained for "treatment and complications" $(39.23 \pm 6.80)$ and the lowest mean score was obtained for "feelings related to condition" (19.45 \pm 4.70$)$ (Table 1$)$.

Table 2 presents the most important five learning needs of the patients after thyroidectomy. The patients ranked

Table 1. Patients' Learning Needs Subscales Mean Scores $(\mathbf{n}=\mathbf{2 5 1})$

\begin{tabular}{lccc}
\hline Subscales & Number of items & Mean & SD \\
\hline Medications & 8 & 34.41 & 5.45 \\
Activities of living & 9 & 37.13 & 6.96 \\
Community and follow-up & 6 & 23.80 & 5.01 \\
Feelings related to condition & 5 & 19.45 & 4.70 \\
Treatment and complications & 9 & 39.23 & 6.80 \\
Enhancing quality of life & 8 & 34.27 & 5.60 \\
Skin care & 5 & 20.06 & 4.13 \\
\hline TOTAL & 50 & 208.38 & 34.91 \\
\hline
\end{tabular}

Table 2. Rank Order of 5 Most Important Learning Needs of Patients'(n=251)

\begin{tabular}{lc}
\hline Learning Need & $\begin{array}{c}\text { Mean score } \\
\mathrm{X} \pm \mathrm{SD}\end{array}$ \\
\hline How to care of cut/incision? & $4.51 \pm 0.77$ \\
How this illness will affect my life? & $4.49 \pm 0.90$ \\
How to take each medication? & $4.49 \pm 0.80$ \\
What complications might occur from my illness? & $4.49 \pm 0.74$ \\
What to do if I have a reaction to the medication? & $4.47 \pm 0.80$ \\
\hline
\end{tabular}


DOI:http://dx.doi.org/10.7314/APJCP.2016.17.3.1479

Determination of Patients' Learning Needs after Thyroidectomy

Table 3. Comparison of Patients' Learning Needs Subscales Mean Scores According to Patients' Characteristics $(\mathbf{n}=\mathbf{2 5 1})$

\begin{tabular}{|c|c|c|c|c|c|c|c|c|}
\hline \multicolumn{9}{|c|}{ Patients' Learning Needs Subscales } \\
\hline Characteristics & Medications & $\begin{array}{l}\text { Activities of } \\
\text { living }\end{array}$ & $\begin{array}{l}\text { Community } \\
\text { and follow-up }\end{array}$ & $\begin{array}{c}\text { Feelings } \\
\text { related to } \\
\text { condition }\end{array}$ & $\begin{array}{l}\text { Treatment and } \\
\text { complications }\end{array}$ & $\begin{array}{l}\text { Enhancing } \\
\text { quality of life }\end{array}$ & Skin care & TOTAL \\
\hline \multicolumn{9}{|l|}{ Age* } \\
\hline $20-35$ & $33.28 \pm 6.53$ & $69.20 \pm 14.92$ & $22.48 \pm 5.77$ & $18.26 \pm 5.44$ & $38.33 \pm 7.19$ & $34.02 \pm 6.69$ & $34.15 \pm 8.18$ & $202.17 \pm 40.54$ \\
\hline $36-50$ & $35.18 \pm 4.20$ & $71.69 \pm 11.30$ & $24.45 \pm 4.42$ & $20.17 \pm 4.29$ & $40.24 \pm 7.19$ & $34.76 \pm 4.87$ & $37.31 \pm 6.40$ & $213.62 \pm 29.60$ \\
\hline $51-65$ & $34.06 \pm 6.28$ & $68.18 \pm 14.63$ & $23.49 \pm 5.29$ & $18.91 \pm 4.84$ & $38.64 \pm 6.47$ & $33.83 \pm 6.10$ & $35.37 \pm 7.90$ & $204.72 \pm 38.42$ \\
\hline \multirow[t]{3}{*}{$\geq 66$} & $34.45 \pm 4.62$ & $70.58 \pm 11.24$ & $24.58 \pm 4.54$ & $20.41 \pm 3.83$ & $38.70 \pm 5.12$ & $34.16 \pm 4.58$ & $36.91 \pm 7.13$ & $210.29 \pm 30.29$ \\
\hline & KW:2.302 & $\mathrm{KW}: 2.546$ & KW:4.345 & KW:5.580 & KW:1.618 & KW:1.164 & KW:5.904 & KW:2.830 \\
\hline & $\mathrm{p}>0.05$ & $\mathrm{p}>0.05$ & $\mathrm{p}>0.05$ & $\mathrm{p}>0.05$ & $\mathrm{p}>0.05$ & $\mathrm{p}>0.05$ & $\mathrm{p}>0.05$ & $\mathrm{p}>0.05$ \\
\hline \multicolumn{9}{|l|}{ Gender** } \\
\hline Female & $34.50 \pm 5.72$ & $70.93 \pm 13.25$ & $23.94 \pm 5.20$ & $19.69 \pm 4.75$ & $39.28 \pm 6.03$ & $34.51 \pm 5.70$ & $36.57 \pm 7.59$ & $209.92 \pm 35.82$ \\
\hline \multirow[t]{3}{*}{ Male } & $34.11 \pm 4.50$ & $67.06 \pm 12.43$ & $23.35 \pm 4.36$ & $18.66 \pm 4.48$ & $39.08 \pm 8.90$ & $33.51 \pm 5.25$ & $34.53 \pm 6.46$ & $203.48 \pm 31.64$ \\
\hline & $\mathrm{t}: 0.484$ & $\mathrm{t}: 1.999$ & $\mathrm{t}: 0.805$ & t: 1.484 & $\mathrm{t}: 0.203$ & $\mathrm{t}: 1.202$ & $\mathrm{t}: 1.876$ & $\mathrm{t}: 1.247$ \\
\hline & $\mathrm{p}>0.05$ & $\mathrm{p}<0.05$ & $\mathrm{p}>0.05$ & $\mathrm{p}>0.05$ & $\mathrm{p}>0.05$ & $\mathrm{p}>0.05$ & $\mathrm{p}>0.05$ & $\mathrm{p}>0.05$ \\
\hline \multicolumn{9}{|l|}{ Marital status** } \\
\hline Married & $34.39 \pm 5.35$ & $70.10 \pm 12.83$ & $23.88 \pm 4.92$ & $19.59 \pm 4.51$ & $39.27 \pm 6.75$ & $34.32 \pm 5.37$ & $36.16 \pm 7.28$ & $208.76 \pm 33.78$ \\
\hline \multirow[t]{3}{*}{ Single } & $34.50 \pm 5.95$ & $69.56 \pm 14.64$ & $23.40 \pm 5.45$ & $18.75 \pm 5.49$ & $39.09 \pm 7.11$ & $34.04 \pm 6.65$ & $35.70 \pm 7.85$ & $206.56 \pm 40.21$ \\
\hline & $\mathrm{t}: 0.115$ & $\mathrm{t}:-0.244$ & $\mathrm{t}:-0.576$ & $\mathrm{t}:-0.958$ & $\mathrm{t}:-0.159$ & t:-0.299 & $\mathrm{t}:-0.375$ & $\mathrm{t}:-0.379$ \\
\hline & $\mathrm{p}>0.05$ & $\mathrm{p}>0.05$ & $\mathrm{p}>0.05$ & $\mathrm{p}>0.05$ & $\mathrm{p}>0.05$ & $\mathrm{p}>0.05$ & $\mathrm{p}>0.05$ & $\mathrm{p}>0.05$ \\
\hline \multicolumn{9}{|l|}{ Education level* } \\
\hline Illiterate & $32.90 \pm 7.54$ & $67.85 \pm 16.84$ & $23.33 \pm 6.12$ & $19.95 \pm 5.24$ & $37.57 \pm 8.62$ & $33.14 \pm 7.17$ & $35.66 \pm 9.52$ & $202.85 \pm 46.64$ \\
\hline Primary school & $34.27 \pm 5.77$ & $69.82 \pm 13.52$ & $24.24 \pm 5.19$ & $19.73 \pm 4.54$ & $39.54 \pm 7.98$ & $34.39 \pm 5.68$ & $36.14 \pm 7.87$ & $209.31 \pm 36.01$ \\
\hline \multicolumn{9}{|c|}{ Secondary school } \\
\hline \multirow{4}{*}{$\begin{array}{l}\text { High school } \\
\text { and higher }\end{array}$} & $34.81 \pm 3.63$ & $72.65 \pm 8.73$ & $24.71 \pm 3.68$ & $20.55 \pm 4.07$ & $39.73 \pm 3.80$ & $34.81 \pm 4.67$ & $37.86 \pm 5.20$ & $214.26 \pm 24.44$ \\
\hline & $34.73 \pm 5.18$ & $69.60 \pm 13.35$ & $23.08 \pm 4.99$ & $18.59 \pm 4.88$ & $39.09 \pm 5.94$ & $34.18 \pm 5.52$ & $35.39 \pm 7.03$ & $206.26 \pm 34.53$ \\
\hline & KW:.687 & KW:.682 & KW:4.721 & KW:6.088 & KW:.150 & KW:1.014 & KW:3.072 & KW:1.470 \\
\hline & $\mathrm{p}>0.05$ & $\mathrm{p}>0.05$ & $\mathrm{p}>0.05$ & $\mathrm{p}>0.05$ & $\mathrm{p}>0.05$ & $\mathrm{p}>0.05$ & $\mathrm{p}>0.05$ & $\mathrm{p}>0.05$ \\
\hline \multicolumn{9}{|c|}{ Concern status about home-care $* *$} \\
\hline Yes & $35.60 \pm 3.96$ & $38.40 \pm 6.63$ & $24.97 \pm 4.42$ & $20.50 \pm 4.03$ & $40.87 \pm 4.36$ & $35.45 \pm 4.43$ & $20.87 \pm 3.31$ & $216.67 \pm 28.44$ \\
\hline \multirow[t]{3}{*}{ No } & $34.18 \pm 5.66$ & $36.89 \pm 7.01$ & $23.58 \pm 5.09$ & $19.25 \pm 4.79$ & $38.92 \pm 7.14$ & $34.05 \pm 5.78$ & $19.91 \pm 4.26$ & $206.81 \pm 35.85$ \\
\hline & $\mathrm{t}: 1.504$ & $\mathrm{t}: 1.258$ & $\mathrm{t}: 1.615$ & $\mathrm{t}: 1.545$ & $\mathrm{t}: 2.297$ & $\mathrm{t}: 1.450$ & $\mathrm{t}: 1.349$ & $\mathrm{t}: 1.923$ \\
\hline & $p>0.05$ & $p>0.05$ & $\mathrm{p}>0.05$ & $\mathrm{p}>0.05$ & $\mathrm{p}<0.05$ & $\mathrm{p}>0.05$ & $p>0.05$ & $p<0.05$ \\
\hline
\end{tabular}

*Kruskal Wallis and **Student-t tests were used

their most important information needs to be "How to care of cut/ incision?" (4.51 \pm 0.77$)$, "How this illness will affect my life?" $(4.49 \pm 0.90)$, "When to stop taking each

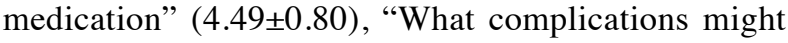
occur from my illness" $(4.49 \pm 0.74)$ and "What to do if I have a reaction to the medication?" $(4.47 \pm 0.80)$ (Table 2$)$.

Table 3 presents some characteristics of patients and the comparison of the mean scores of the patients on the PLNS subscales. The PLNS total mean score of the patients aged between 20 and 35 years was $202.17 \pm 40.54$, that of the patients aged between 36 and 50 years was $213.62 \pm 29.60$, that of the patients aged between 51 and 65 years was $204.72 \pm 38.42$ and that of those aged 66 years or older was $210.29 \pm 30.29$. There was no statistically significant difference between the PLNS mean scores and age of patients ( $>00.05)$. The PLNS mean score of female patients was $209.92 \pm 35.82$ and that of male patients was $203.48 \pm 31.64$. No statistically significant difference was found between the PLNS total mean scores and gender of patients $(\mathrm{p}>0.05)$, whereas, a statistically significant difference was noted in the "activities of living" subscale $(\mathrm{p}<0.05)$. The PLNS and subscales mean scores of married patients were higher $(208.76 \pm 33.78)$ whereas no significant difference was found between marital status and the scale and subscales mean scores ( $>00.05)$. There was no statistically significant difference between level of education and the PLNS and subscales total mean scores $(p>0.05)$, whereas, the patients with secondary education level had higher mean scores (214.26 \pm 24.44$)$. It was found that the PLNS mean score of patients who had concerns about home-care at discharge was higher $(216.67 \pm 28.44)$ and the difference between the PLNS mean score and the mean score for the subscale of "treatment and complications" was statistically significant $(\mathrm{p}<0.05)$ (Table 3).

\section{Discussion}

Today, in the absence of any complications, a long hospitalization is not contemplated in patients undergoing thyroidectomy and the patients are discharged in a short time. The tendency for short-stay thyroidectomy deters nurses from spending enough time with patients to provide discharge education. In this context, learning needs should 
be assessed using correct tools for the correct identification of patients' discharge learning needs and priorities. This study demonstrated patients' high information needs using the PLNS scale (Table 1). Previous studies using the PLNS scale (Tasdemir et al., 2010; Demirkıran and Uzun, 2012; Erdogan, 2012; Dag et al., 2014) also reported that patients had high information needs prior to discharge, which is also consistent with our findings. On the other hand, a study of 45 surgical patients by Jacobs (2000) reported a PLNS total mean score of $106.2 \pm 48.6$ and a study of cardiac catheterization patients by Carew (1999) reported a PLNS total mean score of $111.53 \pm 38.81$, which both are lower than that found in this study (Carew, 1999; Jacobs, 2000). The higher mean score on the PLNS in this study compared to those in the latter two studies can be attributed to differences in patients' demographic characteristics, types of surgical procedures, patient education policies in the countries and institutions the studies were conducted in.

Nurses are supposed to develop new strategies to provide an effective discharge education directed at patients' educational needs. In the process of developing these strategies, it is of great importance to identify patients' priorities and primary information needs. In this study, patients ranked the most important five information needs to be "How to care of cut/ incision?", "How this illness will affect my life?", "When to stop taking each medication", "What complications might occur from my illness" and "What to do if I have a reaction to the medication?" (Table 2).

A study of neurosurgery patients by Tasdemir et al. (2010) reported that the most important five learning needs of the patients were "What the possible side effects of my treatment are", "How to manage the symptoms I have", "How this illness will affect my life" "How this illness will affect my future" and "When to stop medicine" (Tasdemir et al., 2010). A study of 212 patients undergoing hip arthroplasty by Johansson et al. (2002) reported that the most important information for the patients was "how to recognize complications" (Johansson, Huplı and Salantera, 2002).

In a study by Clark and Lan (2004), the most important learning need of patients was reported to be "what are the signs and symptoms of complications that may develop after discharge" (Clark and Lan, 2004). The results of this and similar studies suggest that nurses should focus particularly on issues related to treatment and complications and medications in the process of planning and providing discharge education to patients undergoing a surgical procedure.

It was found that patients' age, gender, and marital status had no effect on patients' learning needs, however, female patients identified the area of "activities of living" more important as a learning need and those who had concerns about home care had higher information need in the domain of" treatment and complications" (Table 3). The result of this study is consistent with those previously reported in other studies (Suhonen et al., 2005; Erdogan, 2012; Tan et al., 2013), which might have resulted from the fact that female patients perceived home care after discharge as a more important learning need as compared to male patients. Postoperatively, patients can experience concerns about possible complications after treatment and discharge and how to manage them. After thyroidectomy, an impaired cosmetic appearance due to visible surgical incision, concerns about loss of voice or impaired voice quality (Cutclife and Herth, 2002), as well as, patients' and families' lack of knowledge on home care can drive patients into concerns and fears about everything that have been said and done previously (Toksal, 2005). The results of this study suggest that patients experience concerns and anxiety about post-discharge complications after thyroidectomy and these concerns may be promoted by the inability of provision of appropriate discharge education, which are also consistent with the literature.

One of the limitations of this study is that it included patients undergoing thyroidectomy in the Endocrine Surgery unit of only one university hospital. Therefore the results of this research represent only the mentioned unit. One of the other limitations is that the data were collected based on self-reporting.

In conclusion, It is important to determine patients' learning needs in terms of their priority through the use of appropriate measurements to provide patients with effective education and enhance the quality of their care. This study demonstrated that the patients, in the unit the study had been conducted, had high information needs and had greater concerns and anxiety particularly about treatment and complications. Nurses should recognize and evaluate the learning needs of their patients. These results are also important to nurses who work in practical fields.

\section{References}

Bailey J (2004). Patient and nurses' perceptions of the cardiac patient's learning needs. The Florida State University School of Nursing. Master Thesis. USA: Florida.

Bubela N., Galloway S, McCay E, et al (1990). The patient learning needs scale: Reliability and validity. $J$ Advanced Nurs, 15, 1181-7.

Carew D (1999). Discharge information needs of outpatient cardiac catheterization patients. department of nursing science. master thesis. university of toronto, Canada.

Clark JC, Lan VM (2004). Heart failure patient learning needs after hospital discharge. Applied Nurs Res, 17, 150-7.

Clark PA, Drain M, Gesell SB, et al (2005). Patient perceptions of quality in discharge instruction. Patient Education Counseling, 59, 56-68.

Cutcliffe Jr, Herth K (2002). The concept of hope in nursing 1: Its origins, background and nature. British J Nurs, 11, 832-40.

Catal E, Dicle A (2008). Hasta ogrenim gereksinimleri olcegi'nin turkiye'de gecerlik ve guvenirlik calısması (A validity and reliability study of the patient learning needs scale in Turkey). Dokuz Eylul Universitesi Hemsirelik Yuksekokulu Dergisi, 1, 19-32.

Dag H, Donmez S, Gulec D, et al (2014). Jinekolojik operasyon geciren kadınların taburculuk oncesi ogrenim gereksinimleri (Learning needs of gynelogical surgery patients before discharge). Ege Universitesi Hemsirelik Fakultesi Dergisi, 30, 49-59.

Demirkıran G, Uzun O (2012). Koroner arter bypass greft ameliyatı geciren hastaların taburculuk sonrası ogrenim gereksinimleri (Post-discharge learning needs of patients who had undergone coronary artery bypass grafting surgery). Ege Universitesi Hemsirelik Fakultesi Dergisi, 28, 1-12. 
Erdogan M (2012). Acık kalp ameliyati olan hastalarin bilgilenme gereksinimlerinin belirlenmesi (Determining the educational requirements of the patients with openheart surgery). Saglik Bilimleri Enstitusu Hemsirelik Anabilim Dali. Yayinlanmamis Yuksek Lisans Tezi. Baskent Universitesi. Turkiye: Ankara.

Falvo DR (2011). Effective patient education: a guide to increased adherence. sudbury, ma: jones-barlett publishers.

Fedai T, Cetin M, Teke A (2010). Tedavi surecindeki gereksiz degiskenliklerin pareto analizi ile degerlendirilmesi (Assessment unnecessary variations in the treatment process with pareto analysis). Saglık Bilimleri Dergisi, 19, 184-90.

Galdeano, LE, Furuya RK, Rodrigues MA, et al (2014). Reliability of the Cardiac Patients Learning Needs Inventory (CPLNI) for use in Portugal. J Clin Nurs, 23, 1532-40.

Jacobs V (2000). Informational needs of surgical patients following discharge. Applied Nur Res, 13, 12-8.

Johansson K, Huplı M, Salantera S (2002). Patients' learning needs after hip arthoplasty. J Clin Nurs, 11, 634-9.

Johansson K, Salantera, S, Katajisto J (2007). Empowering orthopaedic patients through preadmission education: results from a clinical study. Patient Education Counselling, 66, 84-91.

Kizıl C (2008). Kalp yetmezligi olan hastalarin egitim gereksinimleri ve hemsirelerin bu konuda dusunceleri (The education requirement of the patient with heart failure and the nurses' thoughts about this). Saglik Bilimleri Enstitusu İc Hastaliklari Hemsireligi Anabilim Dali. Yayinlanmamis Yuksek Lisans Tezi. Dokuz Eylul Universitesi. Turkiye: Izmir.

McmurrayA, Johnson P, Wallis M, et al (2007). General surgical patients' perspectives of the adequacy and appropriateness of discharge planning tofacilitate health decision-making at home. J Clinical Nurs, 16, 1602-9.

Moderchai BB, Herman A, Kerzman H, et al (2010). Structured discharge education improves early outcome in orthopedic patients. Int J Orthopaedic Trauma Nurs, 14, 66-74.

Myers J, Pellino TA (2009). Developing new ways to address learning needs of adult abdominal organ transplant recipients. Progress Transplantat, 19, 160-6.

Perera A, Patel S, Law N (2014). Thyroid surgery as a 23-hour stay procedure. Ann Royal College Surgeons England, 96, 284-8.

Piredda M, Rocci L, Gualandi R, et al (2008). Survey on learning needs and preferred sources of information to meet the seneeds in Italian oncology patients receiving chemotherapy. Eur J Oncol Nurs, 12, 120-6.

Rutledge J, Siegel E, Belcher R, et al (2014). Barriers to samedaydischarge of patients undergoing total and completion thyroidectomy. Otolaryngology-Head Neck Surgery, 150, $770-4$.

Snyder S, Hamid KS, Roberson CR, et al (2010). Out patient thyroidectomy is safe and reasonable: experience with more than 1.000 planned out patient procedures. J Am College Surgeons, 210, 575.

Suhonen R, Nenonen H, Laukka A, et al (2005). Patient's informational needs and informational received do not correspond in hospital. J Clinical Nursing, 14, 1167.

Sendir M, Buyukyılmaz F, Musovi D (2013). Patients' discharge information needs after total hip and knee arthroplasty: A quasi-qualitative pilot study. Rehabilitat Nurs, 38, 264-71.

Tan M, Ozdelikara A, Polat H (2013). Hasta ogrenim gereksinimlerinin belirlenmesi (Determination of patient learning needs). Florence Nightingale Hemsirelik Dergisi, 2, 1-8.

Tasdemir N, Guloglu S, Turan Y, et al (2010). Learning needs of neurosurgery patients. J Neurological Sci, 27, 414-20.
Determination of Patients' Learning Needs after Thyroidectomy

Tasocak G (2003). Hasta egitimi (Patient education). İstanbul: İ.U. Basım ve Yayınevi Mudurlugu.

Terris DJ, Snyder S, Carneiro-Pla D, et al (2013). American thyroid association statement on outpatient thyroidectomy. Thyroid, 23, 1193-202.

Toksal M (2005). Preoperatif donemde hastalarin hemsirelerden beklentilerinin arastırılması (Investigation of patients expectations from nurses before the operation). Saglik Bilimleri Enstitusu Hemsirelik Anabilim Dali. Yayinlanmamis Yuksek Lisans Tezi. Afyon Kocatepe Universitesi. Turkiye: Afyonkarahisar.

Vrabec S, Oltmann SC, Clark N, et al (2013). A short-stay unit for thyroidectomy patients increases discharge efficiency. $J$ Surg Res, 184, 204-8.

Williams B (2008). Supporting self-care of patients following general abdominal surgery. J Clin Nur, 17, 584-92.

Krishnatreya M, Kataki AC, Sharma JD, et al (2014). Educational Levels and Delays in Start of Treatment for Head and Neck Cancers in North-East India. Asian Pac J Cancer Prev, 15, 10867-9. 